\title{
Research on the Current Situation of Grass-roots Administrators of Colleges and Universities--Based on a Survey in Ten Colleges in Beijing
}

\author{
Jing-Xia SHI \\ Human Resource Division, Beihang University, Beijing, China \\ shijingxia@buaa.edu.cn
}

Keywords: grass-roots administrators, survey of current situation, countermeasures

Abstract: Grass-roots administrators play a crucial role in the management and services of universities. This paper investigates the status quo of grass-roots administrators in 10 colleges and universities in Beijing from four aspects, which are basic information, job satisfaction, learning and training, and living conditions. According to the survey results, the countermeasures are proposed from three aspects which are value concept, professional level promotion, and incentive mechanism.

\section{Introduction}

In the administration of colleges and universities, grass-roots administrative staff is at the frontline of serving teachers and students and play a crucial role in the quality of management and services. Under the background of the China's construction plan of world-class universities and first-class disciplines, the innovation of scientific research, the strengthening of teaching work, and the construction of a high-quality teaching staff have brought arduous tasks and challenges to the administration of colleges and universities. However, most universities in China pay much more attention to the construction of the teaching staff than the administrative staff. How do administrators themselves think of their work and life? In view of this, this article focuses on the survey of the status quo of grass-roots administrative personnel in some colleges and universities in Beijing, with a view to helping the construction of university administrative management team.

\section{Literature Review}

Some domestic researches on grass-roots administrative staff in universities focused on job burnout(Ai-xia Chu ${ }^{[1]}$,Tian Zheng/Xin-qiang Shong ${ }^{[2]}$, Hui-qin Wang/Yi-ping $\mathrm{He}^{[3]}$, An-qi Zhang ${ }^{[4]}$ ), Xiao-yu Gong and Jian-wei Zou explored the orientation and development of grass-roots administrative personnel in the context of big ministry system reform from the perspective of schools and individuals ${ }^{[5]}$, Yan Peng analyzed the relationship between grass-roots administrative staff's work values and professionalism, proposed to improve their dedication by formulating reasonable remuneration, ensuring career development, and improving training system ${ }^{[6]}$. Le-zheng Yu analyzed and studied the occupational puzzles, career trends and countermeasures of grass-roots administrative staff in colleges ${ }^{[7]}$. It can be found through the literature review that few scholars have conducted research on the status quo of the work and life of the administrative staff at the grassroots level. In view of this, this paper focuses on an empirical survey of the status quo of grass-roots administrative staff in some colleges and universities in Beijing, with a view to add the research contents of this field.

\section{Design of the Questionnaire}

The structure of the questionnaire has the following four aspects: First, the basic information of the survey objects, including gender, age, marital status, children's situation, education (degree), speciality, professional title, years of administrative work, annual income etc. The second is the job satisfaction survey which mainly adopts the questions designed by Wei-fen Chen in her research paper $\left.{ }^{[8}\right]$, in this part we make the job satisfaction survey from seven dimensions, such as work itself, remuneration and benefits, work relationships, work pressure, working conditions, work status, and 
organizational climate. The third is the situation of advanced studies and training, which mainly includes whether the surveyed persons have plans to upgrade their academic degrees, the obstacles in studying a higher level of academic degree, and the training contents that they hope to carry out. The fourth is the living conditions of the surveyed subjects, including whether they feel stressed, the source of the stress, and the problems that need to be resolved urgently.

\section{Sources of the Sample}

The questionnaire was published on the internet, the survey respondents mainly come from 10 colleges and universities in Beijing. The universities are "985 Project" colleges, "211 Project" colleges, and general ones in terms of the type of colleges and universities; they are affiliated to the Ministry of Industry and Information Technology, the Ministry of Education, Beijing City and other institutions, and they are comprehensive colleges, universities of science and engineering, normal colleges, and other specialty colleges in terms of category. So the survey scope has a certain representativeness.

A total of 205 valid questionnaires were collected in the survey, including 6 directors, 16 deputy directors and 183 grass-roots administrators. The samples from the 183 grass-roots administrators are the focus of the analysis in this paper.

\section{Analysis of the survey results}

\subsection{Basic Information of the Respondents}

From Table 1, it can be seen that women are twice as men among the 183 grass-roots administrators surveyed in colleges and universities, this may be relevant to the fact that women are more likely to accept the repeated administrative tasks, and their desire for job promotion is not too strong; young and middle-aged people aged 26 to 40 are the main part in terms of age; in terms of marriage and children, married persons are the main players, and their children are distributed in all age groups. The proportion of masters in the academic structure is much greater than that of undergraduates and below, indicating that the level of academic qualifications for administrative work is getting higher and higher. Respondents with middle professional title are the main part in the sample, and respondents who have been taking the administrative job for 6-10 years are on the top of the list, more than half of the respondents whose annual income is less than 150000RMB. 
Table 1. Basic situation of investigation

\begin{tabular}{|c|c|c|c|c|}
\hline \multirow{2}{*}{ Gender } & \multicolumn{2}{|c|}{ Male } & \multicolumn{2}{|c|}{ Female } \\
\hline & \multicolumn{2}{|c|}{$31.69 \%$} & \multicolumn{2}{|c|}{$68.31 \%$} \\
\hline \multirow{2}{*}{ Age } & Under 30 & $31-40$ & $41--50$ & Over 50 \\
\hline & $22.41 \%$ & $55.73 \%$ & $13.66 \%$ & $8.20 \%$ \\
\hline \multirow{2}{*}{ Marriage } & \multicolumn{2}{|c|}{ Married } & \multicolumn{2}{|c|}{ Unmarried } \\
\hline & \multicolumn{2}{|c|}{$82.51 \%$} & \multicolumn{2}{|c|}{$17.49 \%$} \\
\hline \multirow[t]{2}{*}{ Child } & No child & $\begin{array}{c}\text { Children under } 6 \\
\text { years old }\end{array}$ & $\begin{array}{c}\text { Children aged } \\
12-18\end{array}$ & $\begin{array}{l}\text { Children aged } \\
\text { over18 }\end{array}$ \\
\hline & $27.87 \%$ & $38.80 \%$ & $22.40 \%$ & $10.93 \%$ \\
\hline \multirow{2}{*}{ Education } & Junior college & Undergraduate & Master's degree & Doctor's degree \\
\hline & $2.19 \%$ & $10.93 \%$ & $72.13 \%$ & $14.75 \%$ \\
\hline \multirow[t]{2}{*}{ Speciality } & $\begin{array}{c}\text { Literature and } \\
\text { History }\end{array}$ & $\begin{array}{c}\text { Education and } \\
\text { management }\end{array}$ & $\begin{array}{l}\text { Science and } \\
\text { engineering }\end{array}$ & Others \\
\hline & $14.75 \%$ & $32.79 \%$ & $46.45 \%$ & $6.01 \%$ \\
\hline \multirow{2}{*}{$\begin{array}{l}\text { Professional } \\
\text { title }\end{array}$} & Primary rank & Middle rank & Deputy senior & Senior \\
\hline & $13.11 \%$ & $75.96 \%$ & $10.93 \%$ & $4.37 \%$ \\
\hline \multirow{2}{*}{$\begin{array}{c}\text { Years of } \\
\text { administrative } \\
\text { work }\end{array}$} & $0-5$ & $6-10$ & $11-15$ & more than 16 \\
\hline & $34.43 \%$ & $38.25 \%$ & $12.02 \%$ & $15.30 \%$ \\
\hline \multirow{2}{*}{$\begin{array}{l}\text { Annual } \\
\text { income } \\
\text { (RMB) }\end{array}$} & 50000--100000 & $100000-150000$ & $150000-200000$ & $\begin{array}{c}\text { more than } \\
200000\end{array}$ \\
\hline & $26.23 \%$ & $66.12 \%$ & $7.10 \%$ & $0.55 \%$ \\
\hline
\end{tabular}

\subsection{Job Satisfaction of the Respondents}

The part of job satisfaction in the questionnaire has seven dimensions and 48 factors, the seven dimensions are work itself, remuneration and benefits, work relationships, work pressure, working conditions, work position, and organizational climate. According to the degree of recognition, there are five answer options for each factor in the questionnaire range from strongly agree to strongly disagree. The answer option was calculated by Likert's 5-point scoring method. The scores are calculated as 5 points, 4 points, 3 points, 2 points, and 1 point successively from strongly agree to strongly disagree. It is counted by SPSS19.0,and the main result is as follows.

Table 2. Descriptive statistics

\begin{tabular}{|l|c|c|c|c|c|}
\hline \multicolumn{1}{|c|}{ dimensions } & samples & minimum & maximum & mean & $\begin{array}{c}\text { standard } \\
\text { deviation }\end{array}$ \\
\hline work itself & 183 & 1.00 & 5.00 & 3.2921 & .74591 \\
remuneration and benefits & 183 & 1.00 & 4.83 & 2.7514 & .69664 \\
organizational climate & 183 & 1.00 & 5.00 & 3.2842 & .76065 \\
work position & 183 & 1.00 & 5.00 & 2.8626 & .81315 \\
work pressure & 183 & 1.00 & 4.80 & 2.7880 & .67877 \\
work relationships & 183 & 1.00 & 5.00 & 3.5792 & .73620 \\
working conditions & 183 & 1.00 & 5.00 & 3.4254 & .68117 \\
valid N (list status) & 183 & & & & \\
\hline
\end{tabular}

The survey results show that the job satisfaction of grass-roots administrative staff in colleges and universities is not optimistic. The average value of most of the surveyed dimensions is slightly higher than the median, which shows that the respondents are generally satisfactory. The averages 
of other dimensions are below the mean which shows that the respondents are in the status of dissatisfaction.

From Table 2, it can be seen that in the seven dimensions surveyed, the average score of the working relationships is the highest, it is 3.5792, which shows that the relationship between leaders, subordinates and colleagues in the management institutions in colleges and universities is in an ideal state. The average score of working condition is 3.4254, which indicates that the respondents are relatively satisfied with the working conditions. This is due to the improvement of the conditions in universities in recent years. The average scores of the work itself and the organizational climate are relatively close, they are 3.2921 and 3.2842 respectively, which are slightly higher than the median, and which shows that the respondents are basically satisfied with the basic administrative work and the atmosphere of the university. The average score of work position is 2.8626, which is lower than the median and shows that the respondents' satisfaction with their job position is negative. This may be related to the practice of paying much more attention to the scientific research than administrative management in most universities. The average score of work stress is 2.7880 , which shows that the respondents are not satisfied and coincides with the result of the question in the fourth part of the questionnaire in which the respondents think that pressure comes from work accounts for $47.5 \%$ in the total pressure sources. The score of remuneration and benefits is the lowest among all dimensions, it is 2.7514 . It can be seen that the respondents are not satisfied with the remuneration and benefits.

\subsection{Learning and Training status of the Respondents}

This part mainly investigates the following three aspects: improvement of education, that is, achieving a higher academic qualification, obstacles in the process of achieving a higher academic qualification, and the training program that hoped to be provided. The results show that $17.5 \%$ of the respondents are studying for a higher education level, $45 \%$ are preparing to apply for examination, $20 \%$ of them are tangled or do not apply, and other $17.5 \%$ of the survey respondents do not have plans to improve their academic qualifications.

In terms of obstacles in improving academic qualifications, the conflict between work and study , the conflict between family and study, the difficulty of finding a tutor especially for those who plans to get a doctor's degree, and the lack of basic knowledge related to management professionals are the top four on the list of survey results. It can be seen that work, family, tutors, and professional knowledge have caused problems for the promotion of academic qualifications.

Regarding the question of "what kinds of knowledge do you want to be trained on?", $60.66 \%$ of the respondents selected the answer of "business knowledge required for the job", and other options in descending order are career guidance, school policy and planning, mental health guidance, time management, national education-related policies, and personal relationship training. Among them, $64 \%$ and $56 \%$ of the respondents who are engaged in the administrative work for less than ten years are expected to get job business knowledge training and career guidance, showing very obvious characteristics, but other training contents had no obvious fixed population.

\subsection{Living Conditions of the Respondents}

$43.17 \%$ of respondents think that their current life is under quite a pressure, and $18.03 \%$ believe that the pressure is high. The survey results show that income, work, housing, and children's education are the major causes of stress in life, which is consistent with the current social status in Beijing. For the question of "current problems that needed to be solved urgently", the top four options are promotion of professional titles, promotion of job titles, earning money and house purchasing, their proportions account for $21.31 \%, 20.22 \%, 13.66 \%$, and 12.57 respectively. According to the data, the respondents who feel pressure for life have an annual income below 150,000 RMB and their children are under 12 years old.

\section{Thoughts and Countermeasures on Strengthening the Construction of Grass-roots Administrators in Colleges and Universities}


Grass-roots administrative staff forms a connecting link in the administrative management of colleges and universities, but the construction and development of the team is faced with the test of value concepts, professional level enhancement, and incentive mechanisms. In this respect, it is recommended to strengthen the team building of grassroots administrative personnel in colleges and universities from the following three aspects.

\subsection{Promoting Social Status and Enhancing Job Pride}

The phenomenon of paying much more emphasis to the scientific research and teachers than the administrative staff has been existing for a very long time in colleges and universities, which led to the result that managers especially grass-roots executives have no sense of existence. This can be seen from the score of work position in the job satisfaction survey in the fourth part. To this end, it is necessary to formulate relevant institutional measures to improve their social status, and give consideration to the development of management personnel while introducing development policies for teachers, so that they can enjoy the same treatment and position as full-time teachers. The above measures can satisfy the administrator's eagerness to obtain respect and recognition, and to increase their job pride.

\subsection{Strengthening Professional Knowledge Training and Improving Management Service Level}

The administrative management in the university is a science with its own unique theoretical system and laws. However, the fact is that the professional structure of grassroots administrative personnel in colleges and universities is quite diversified, and the phenomenon that most administrative staff are much more engaged in daily work than getting trained. Therefore, it is necessary to strengthen management knowledge training for management personnel and formulate regular learning and training plans for grassroots administrative personnel according to actual needs, especially the external learning exchanges, so that managers can go out, keep abreast of industry trends, fully experience and absorb good practices, expand their horizons and improve their professional skills and business knowledge.

\subsection{Improving the Incentive Mechanism and Mobilizing the Work Enthusiasm}

Most of the grass-roots administrative personnel in colleges and universities make a career development by improving their professional titles or administrative titles. However, the reality is that there are a limited number of posts in administrative positions, and professional posts need to publish a certain number of academic articles, which bring certain difficulties and dampen the enthusiasm for the work for the front-line administrative personnel who are mainly engaged in the daily routine. Therefore, it is necessary to explore and establish a salary and incentive system suitable for administrators in universities so that more front-line staff can enjoy the corresponding treatment through their own efforts. This will not only allow them to feel at ease in their posts but also mobilize their consciousness, and above all to pursue career development actively and improve the level of management services enthusiastically.

\section{References}

[1] Ai-xia Chu, Analysis on Causes and Strategies of Professional Burnout of the Administrative Staff in Colleges and Universities from the Perspective of Incentive Theory, Health Vocational Education, 2016 (17) : 19-20.

[2] Tian Zheng, Xinqiang Song, An Empirical Study on Job Burnout of Grass-roots Administrative Staff in Colleges and Universities-- Take a university in Guangdong as an example, Higher Education Exploration, 2014(3):31-34.

[3] Huiqin Wang,Yiping He, Analysis and Countermeasures of Job Burnout of Grass-roots Administrative Staff in Colleges and Universities, Journal of Hunan Institute of Socialism, 2014(6):80-82. 
[4] Anqi Zhang, Research on the Job Burnout and Incentive Strategy of Grass-roots Administrators of Colleges and Universities, 2016.

[5] Xiaoyu Gong, Jianwei Zou, Analysis of the Positioning and Development of the Administrative Staff at the Basic Level in Universities in the Context of Big Ministry System Reform, Science and Technology Innovation Herald, 2017 (3) : 130-132.

[6] Yan Peng, Study on the Relationship between Work Values and Engagement Degree of University Administrative Staff at the Basic Level, Human Resource Management, 2016(5):164.

[7] Lezheng Yu, Fengjuan Liu, Donghua Liu, Talking about the Professional Dilemma and Countermeasures of the Administrative Staff at the Basic Level in Colleges and Universities, Higher Education Forum, 2013(8):97-104.

[8] Weifen Chen, Research on Job Satisfaction of College Management Staff-Based on the Samples from Ningbo City, 2010.

[9] Weijin Nie, Investigation and Analysis of the Status Quo of the Professionalization of Management Staff in Colleges and Universities--take the example of 11 colleges and universities in Jiangsu Province, Heilongjiang Researches on Higher Education, 2012(10):50-54.

[10] Chaoying Meng, Zili Peng, Xijin Weng, Investigation and Research on the Status Quo of Middle Management Cadres in Colleges and Universities, Journal of National Academy of Education Administration, 2011(9):81-85. 